\title{
Pulmonary impact of titanium dioxide nanorods: examination of nanorod-exposed rat lungs and human alveolar cells
}

This article was published in the following Dove Press journal: International Journal of Nanomedicine

\author{
Tamara Horváth' \\ András Papp' \\ Nóra Igaz ${ }^{2}$ \\ Dávid Kovács ${ }^{2}$ \\ Gábor Kozma ${ }^{3}$ \\ Vivien Trenka ${ }^{2}$ \\ László Tiszlavicz ${ }^{4}$ \\ Zsolt Rázga ${ }^{4}$ \\ Zoltán Kónya ${ }^{3}$ \\ Mónika Kiricsi² \\ Tünde Vezér ${ }^{1}$
}

'Department of Public Health, Faculty of Medicine, University of Szeged, Szeged, Hungary; ${ }^{2}$ Department of Biochemistry and Molecular Biology, Faculty of Science and Informatics, University of Szeged, Szeged, Hungary; ${ }^{3}$ Department of Applied and Environmental Chemistry, Faculty of Science and Informatics, University of Szeged, Szeged, Hungary; ${ }^{4}$ Department of Pathology, Faculty of Medicine, University of Szeged, Szeged, Hungary
Background: Titanium dioxide nanoparticles have numerous applications, resulting in human exposure. Nonetheless, available toxicological and safety data are insufficient regarding aspherical particles, such as rod-shaped nanoparticles.

Methods: In a combined in vitro-in vivo approach, cultured A549 lung alveolar adenocarcinoma cells were treated with approximately $15 \times 65 \mathrm{~nm} \mathrm{TiO}$, nanorod-containing medium, while young adult rats received the same substance by intratracheal instillation for 28 days in 5 and $18 \mathrm{mg} / \mathrm{kg}$ body-weight doses. Nanoparticle accumulation in the lungs and consequent oxidative stress, cell damage, and inflammation were assessed by biochemical and histopathological methods.

Results: Titanium was detected in tissue samples by single-particle inductively coupled plasma mass spectrometry. Nanoparticles were visualized inside cultured A549 cells, within pulmonary macrophages, and in hilar lymph nodes of the rats. A549 cells showed dose-dependent oxidative stress and lethality, and the observed nanoparticle-laden endosomes suggested deranged lysosomal function and possible autophagy. Strongly elevated Ti levels were measured in the lungs of nanorod-treated rats and moderately elevated levels in the blood of the animals. Numerous cytokines, indicating acute and also chronic inflammation, were identified in the lung samples of $\mathrm{TiO}_{2}$-exposed rodents.

Conclusion: Several signs of cell and tissue damage were detected in both the cultured alveolar cells and in treated rats' lungs. Rod-shaped nanoparticulate $\mathrm{TiO}_{2}$ may consequently be more harmful than has generally been supposed. The occupational health risk suggested by the results calls for improved safety measures.

Keywords: nanoparticles, toxicity, oxidative stress, autophagy, cytokines, inflammation

\section{Introduction}

Titanium dioxide nanoparticles $\left(\mathrm{TiO}_{2} \mathrm{NPs}\right)$ have numerous industrial applications and appear in various consumer goods, including food, cosmetics, and medicines. This widespread application raises the question of possible human exposure of occupational, environmental, and/or intentional origin with the potential for negative health consequences.

Whenever NPs (particles with at least one dimension $<100 \mathrm{~nm}$ ) are generated, purposefully or as by-products, they are likely to be released into the surrounding atmosphere, where the formation of an extremely stable aerosol is probable. ${ }^{1}$ Consequently, inhalation is a major way of human exposure to NPs present in the immediate (workplace, residential, or other) environment. NPs inhaled with polluted air are either deposited in the nasopharynx or may reach the alveoli in both humans and in rats., ${ }^{2,3}$
Correspondence: András Papp Department of Public Health, Faculty of Medicine, University of Szeged, I0 Dóm Tér, Szeged 6720, Hungary

Tel +3662342870

Fax +3662545 I20

Email papp.andras@med.u-szeged.hu 
Deposition takes place there mainly by diffusion, with highest efficiency for particles or agglomerates of $10-100 \mathrm{~nm}$ diameter. ${ }^{4}$

The relationship between elevated levels of ambient airborne NPs and human morbidity and mortality has been generally accepted. ${ }^{1}$ NPs have large specific surface area, which is also very reactive, leading to the generation of reactive oxygen species (ROS) in the aqueous microenvironment of living tissues. ${ }^{5}$ The resulting oxidative stress can overwhelm cellular antioxidant defense mechanisms and induce inflammation via activation of the MAPK and NF $K B$ pathways, ending up in the release of cytokines. ${ }^{5}$ NPs can affect the mitochondria directly and interfere with oxidative phosphorylation, resulting in the generation of even more ROS, thereby aggravating oxidative stress and initiating apoptosis. ${ }^{6}$ From a mechanistic perspective, ROS generation and oxidative stress make up the best-developed paradigm to explain the toxic effects of inhaled NPs. Since there appears to be a direct relationship between the surface area of NPs, their ROS-generating capacity, and proinflammatory effects induced by particles in the lung, ${ }^{7}$ biochemical consequences, such as lipid peroxidation or changes in antioxidant-enzyme activities, and in the expression of cytokines, are potential biomarkers of NP toxicity (suitable even for toxicity screening of airborne particles). ${ }^{8}$

Inflammasomes are protein assemblies with a central role in cellular immunoreactions. ${ }^{9}$ ROS induced by NPs directly or via mitochondrial dysfunction, or via effectors like cathepsin B emitted from damaged lysosomes, activate inflammasomes, which in turn activate the interleukin activator caspase $1 .{ }^{10}$ Lysosomal damage itself may result from the presence of NPs due to oxidative membrane damage or the disrupted processing of phagosomes laden with indigestible NPs. Lysosomal leakage and disturbed autophagy may also contribute to NP-provoked inflammation and tissue damage. ${ }^{9}$ Dysfunction of the cytoskeleton, intracellular transport, and/ or lysosomes may lead to abnormal degradation processes and to the release of numerous lysosomal enzymes in the cytoplasm. ${ }^{11}$ On the other hand, autophagy is mutually related to the expression and secretion of certain cytokines, including IL1, IL18, TNF $\alpha$, and IFN1. ${ }^{12}$

The worldwide production of several million tons of $\mathrm{TiO}_{2}$ (including both microscopic and submicroscopic particles) suggests first of all an occupational risk. The National Institute for Occupational Safety and Health has published a limit of $0.3 \mathrm{mg} / \mathrm{m}^{3}$ for ultrafine ( $<100 \mathrm{~nm}$ diameter) $\mathrm{TiO}_{2}$ in the workplace atmosphere. ${ }^{13}$ Actual measurements have proved temporary exceedance of this limit during production and packaging of nano- $\mathrm{TiO}_{2},{ }^{14}$ whereas model calculations have shown a clear positive health risk. ${ }^{15}$ This is in accordance with previous findings proving that workplace exposure to airborne $\mathrm{TiO}_{2}$ results in decreased ventilatory capacity and pleural thickening. ${ }^{16}$

In rat lungs, Yoshiura et $\mathrm{a}{ }^{17}$ evoked transient inflammation with activation of cytokines and antioxidant enzymes by a single intratracheal application of $\mathrm{TiO}_{2} \mathrm{NPs}$ (spheres of $\sim 25 \mathrm{~nm}$ in diameter). In true inhalation exposure in rats, it has been found that the intensity of lung-inflammatory reaction, cytotoxicity, and oxidative stress after a single exposure were dependent on the diameter of the primary NPs and their agglomerates. ${ }^{3}$

Six-hour inhalation of nanosize and pigment-grade $\mathrm{TiO}_{2}$ on 5 consecutive days has induced neutrophilic inflammation in the lungs, together with size-dependently variable deposition of the particles and translocation to local lymph nodes. ${ }^{18}$ The importance of deposition and clearance (dependent on the NPs' characteristics) in causing lung inflammation in rats was also stressed by Oyabu et al. ${ }^{19}$ In vitro exposure to $\mathrm{TiO}_{2}$ NPs of the human lung-related alveolar adenocarcinomaderived A549 cell line ${ }^{20}$ has resulted in moderate cytotoxicity and altered cytokine release within $24-48$ hours..$^{21,22}$

Most experimental results, including the cited ones pointing to the importance of particle size in toxicity, have been obtained with spherical NPs. It has been realized, however, that in certain practical applications, eg, dye-sensitized solar cells ${ }^{23}$ therapeutic applications, ${ }^{24}$ biocompatible implants, ${ }^{25}$ or antimicrobial treatment of fabrics, ${ }^{26}$ other forms (eg, nanorods, nanotubes) are preferable, which adds another aspect (over size and agglomeration) to features potentially influencing the toxicity of NPs, as was concluded recently by Wang and Fan. ${ }^{27} \mathrm{~A}$ recent report on the shape-dependent accumulation of NPs in various organs has revealed that rod- or tube-shaped nanomaterials had a clear advantage in capacity to concentrate in the respiratory system, and thus in lung tissue over their spherical counterparts, ${ }^{28}$ whereas in another study particle size, but not shape, was found to influence pulmonary inflammation. ${ }^{29}$ Related to the increased accumulation potential of nanorods in the lungs, the degree of exerted toxic effects and nature of induced molecular mechanisms might also differ from those of spherical particles.

Experimental data on general and organ-specific toxicity of $\mathrm{TiO}_{2} \mathrm{NPs}$ are numerous, ${ }^{30,31}$ but do not settle all questions of human health risks resulting from exposure to $\mathrm{TiO}_{2} \mathrm{NPs}$. The apparent shortage of knowledge and the fact that the respiratory system is the first to be confronted with airborne NPs shaped our aims. Thus, in the present work, the potential 
harmful effects of $\mathrm{TiO}_{2}$ nanorods on the respiratory tract were investigated. It was examined whether NPs and their effects could be detected in the alveolar part of the airways, which is crucial for respiratory function, and whether the damage induced is acute or chronic in character. To elucidate the pathomechanism, we used a combined in vitro and in vivo experimental approach, where nanorod-exposed rat lungs and lung-derived cell cultures were subjected to histological, chemical, and biochemical analyses.

\section{Methods}

\section{Production and characterization of $\mathrm{TiO}_{2}$ nanorods}

All chemicals for the synthesis of NPs were obtained from Sigma-Aldrich (St Louis, MO, USA). Nanorods of $\mathrm{TiO}_{2} \sim 15 \times 65 \mathrm{~nm}$ in size were synthesized from titanate nanotubes as intermediate products in a simple alkali hydrothermal method as per Madarász et al. ${ }^{32} \mathrm{NaOH}$ solution $(1 \mathrm{~L}, 10 \mathrm{M})$ and $50 \mathrm{~g} \mathrm{TiO}_{2}$ nanopowder (Degussa P25) were mixed in a stainless-steel Teflon-lined autoclave for 24 hours at $428 \mathrm{~K}$ using continuous rotation at $3 \mathrm{rpm}$. The as-prepared $\mathrm{TiO}_{2}$ nanostructures were washed thoroughly with deionized water to neutral $\mathrm{pH}$, subsequently with $0.1 \mathrm{M} \mathrm{HCl}$ several times, and finally with water again to obtain a neutral salt-free product. Finally, the $\mathrm{TiO}_{2}$ nanotubes obtained were heated at $600^{\circ} \mathrm{C}$ for 1 hour in normal air, whereupon $\mathrm{TiO}_{2}$ nanorods evolved. The size, shape, and crystal structure of the product were checked by X-ray diffraction (in a dry state, using the database PDF-4), ${ }^{33}$ dynamic light scattering, and transmission electron microscopy (TEM) after suspending the nanomaterial in the treatment medium (PBS containing 1\% polyacrylic acid [PAA] as stabilizing agent at $\mathrm{pH} 7$ ). Stability of the material was tested by comparing these parameters in a fresh state and after 4 months of storage at $5^{\circ} \mathrm{C}$.

\section{In vitro investigation}

\section{A549 cell culture}

The A549 lung alveolar adenocarcinoma cell line was purchased from the American Type Culture Collection (Manassas, VA, USA). Cells were maintained in low-glucose $(1 \mathrm{~g} / \mathrm{L})$ DMEM (Sigma-Aldrich) complemented with 10\% FBS (Sigma-Aldrich), $2 \mathrm{mM}$ L-glutamine, 0.01\% streptomycin, and $0.005 \%$ ampicillin and cultured under standard conditions in a $37^{\circ} \mathrm{C}$ incubator containing $5 \% \mathrm{CO}_{2}$ in $95 \%$ humidity.

\section{Cell-viability test}

To estimate the effect of $\mathrm{TiO}_{2}$ NPs and PAA alone on the viability of A549 cells, $10^{4}$ cells/well were seeded into 96-well plates and exposed to either $\mathrm{TiO}_{2}$ NPs or PAA for 24, 48, and 72 hours. The suspension of $\mathrm{TiO}_{2} \mathrm{NPs}$ was added to the culture medium to achieve concentrations of $0.025-2 \mathrm{mg} / \mathrm{mL}$, while for cells in separate wells corresponding amounts of PAA were added. After the treatments, the NP- or PAA-containing culture medium was removed and cells incubated with $0.5 \mathrm{mg} / \mathrm{mL}$ yellow MTT reagent (Serva, Heidelberg, Germany) diluted in culture medium for 1 hour at $37^{\circ} \mathrm{C}$. The formazan crystals generated were solubilized in dimethyl sulfoxide (Molar Chemicals, Halásztelek, Hungary) and absorbance at $570 \mathrm{~nm}$ determined using a Synergy HTX plate reader (BioTek, Winooski, VT, USA). MTT measurements were repeated three times using at least four independent biological replicates.

\section{Detection of reactive oxygen species}

To detect the formation of ROS upon nano- $\mathrm{TiO}_{2}$ and PAA exposure, $2^{\prime}, 7^{\prime}$-dichlorofluorescin diacetate (DCFDA; SigmaAldrich) staining was performed. Cells were cultured for 1 day and then treated with $\mathrm{TiO}_{2}$ nanorods or PAA for 48 hours. Again, $\mathrm{TiO}_{2}$ NPs were applied in concentrations ranging of $0.025-2 \mathrm{mg} / \mathrm{mL}$ in the medium, while for cells in separate wells the corresponding amount of PAA was added. After the treatments, cells were washed with PBS, incubated with $10 \mu \mathrm{M}$ DCFDA solution for 1 hour, and fluorescence intensity measured with the Synergy HTX plate reader according to the manufacturer's specifications. The experiment was repeated three times using at least four independent replicates.

\section{Apoptosis detection by annexin $\mathrm{V}$-propidium iodide staining}

The induction of apoptosis by nano- $\mathrm{TiO}_{2}$ exposure of A549 cells was investigated with annexin $\mathrm{V}$-propidium iodide staining. For this purpose, $3 \times 10^{5}$ A549 cells were seeded into six-well plates and left to grow for 24 hours. On the following day, cells were exposed to $0.1 \mathrm{mg} / \mathrm{mL} \mathrm{TiO}_{2}$ NPs or PAA at a corresponding concentration. After 24, 48, and 72 hours of treatment, cells were stained with Alexa488-conjugated annexin $\mathrm{V}$-propidium iodide according to the manufacturer's guidelines (Thermo Fisher Scientific, Waltham, MA, USA). Fluorescence intensity was determined by means of flow cytometry (FACSCalibur; BD, Franklin Lakes, NJ, USA) measuring 10,000 cells and FACS data analyzed with Flow Jo version 10 software. Experiments were repeated three times using at least two biological replicates.

\section{Scanning electron microscopy}

For scanning electron microscopy (SEM) analysis, $3 \times 10^{5}$ A549 cells were seeded onto plastic coverslips (Sarstedt, 
Nümbrecht, Germany), placed in six-well plates, left to grow for 1 day, and then exposed to $0.1 \mathrm{mg} / \mathrm{mL} \mathrm{TiO}_{2} \mathrm{NPs}$ for 24 hours. Following that, cells were washed and fixed using 2.5\% glutaraldehyde (dissolved in modified Sörensen buffer, pH 7.6). Samples were dehydrated by solutions containing increasing percentages of ethanol in water $(50 \%$, $70 \%, 80 \%, 90 \%, 95 \%, 98 \%$, and 100\%, 15 minutes each), followed by a series of tert-butanol:ethanol mixtures $(1: 2$, $1: 1$, and $2: 1$ volume ratio) at room temperature. Then, cells were incubated with tert-butanol overnight, at $4{ }^{\circ} \mathrm{C}$ and finally lyophilized. The coverslips were mounted on specimen stubs using electrically conductive double-sided adhesive tape, and the sample preparation was completed with the application of a 4-5 nm metal gold-palladium coating, needed to decrease charging artifacts and radiation damage of the biological sample. Field-emission SEM imaging was performed with a Hitachi S-4700 using $10 \mathrm{kV}$ accelerating voltage and $10 \mu \mathrm{A}$ emission current. Energydispersive X-ray spectroscopy (EDS) measurements were carried out with a Röntec QX2 EDS detector installed on the S-4700 using $20 \mathrm{kV}$ accelerating voltage and $10 \mu \mathrm{A}$ emission current.

\section{Transmission electron microscopy}

To detect intracellular accumulation of $\mathrm{TiO}_{2}$ NPs in A549 cells, $10^{5}$ cells were seeded onto $0.4 \mu \mathrm{m}$-pore polyestermembrane inserts (Corning, Corning, NY, USA) placed in a six-well plate. On the following day, cells were exposed to $0.1 \mathrm{mg} / \mathrm{mL} \mathrm{TiO}_{2}$ NPs for 24 hours. Treated cells were washed in PBS, fixed in 4\% glutaraldehyde diluted in PBS for 2 hours, and subsequently embedded in gelatin ( $2 \%$ gelatin in PBS). The specimen obtained was sliced to $1-2 \mathrm{~mm}$ cubes, which were further embedded in epoxy (Epon 812; Sigma-Aldrich) by a routine TEM sample-preparation protocol. Semithin sections of $1 \mu \mathrm{m}$ were prepared to identify the cell monolayer. Blocks were trimmed and thin sections of $70 \mathrm{~nm}$ obtained and stained with uranyl and lead solutions. Images were captured with a JEOL 1,400 plus $120 \mathrm{kV}$ using $100 \mathrm{kV}$ voltage.

\section{In vivo investigation}

Animals and treatment

Young adult male specific-pathogen-free Wistar rats (Crl:WIBr, 6 weeks old, 170 20 g body weight [BW]) were used, 40 in all, obtained from Toxi-Coop (Budapest, Hungary). The rats, two per cage, were kept in an animal house providing good laboratory practice-equivalent
Table I Groups and treatments

\begin{tabular}{l|l|l|l}
\hline Control & $\begin{array}{l}\text { Vehicle- } \\
\text { treated }\end{array}$ & $\begin{array}{l}\text { Low } \\
\text { dose }\end{array}$ & $\begin{array}{l}\text { High } \\
\text { dose }\end{array}$ \\
\hline $0.9 \%$ & I\% PAA & $\mathrm{TiO}_{2} \mathrm{NPs}$ & $\mathrm{TiO}_{2} \mathrm{NPs}$ \\
$\mathrm{NaCl}$ & in PBS & $5 \mathrm{mg} / \mathrm{kg} \mathrm{BW}$ & $18 \mathrm{mg} / \mathrm{kg} \mathrm{BW}$ \\
\hline
\end{tabular}

Abbreviations: BW, body weight; PAA, polyacrylic acid; NPs, nanoparticles.

conditions (12/12-hour light/dark cycle with light on at 6 am; temperature $22^{\circ} \mathrm{C} \pm 3{ }^{\circ} \mathrm{C}, 30 \%-70 \%$ relative humidity), with free access to unlimited water and standard rodent food (Ssniff R/M-Z + H; also from Toxi-Coop). After 1 week of acclimation, animals were randomized to four treatment groups of ten rats each, based on spontaneous exploratory activity. Groups and corresponding treatments are shown in Table 1.

Treatment of the rats was performed 5 days/week for 28 days, always between 8 and $10 \mathrm{am}$. The suspension of $\mathrm{TiO}_{2}$ NPs was applied by intratracheal instillation $(1 \mathrm{~mL} / \mathrm{kg}$ BW volume) with brief anesthesia. ${ }^{34}$ Rat BW was measured every morning before treatment to determine the exact daily dose to be instilled and to see the effect of treatment on BW gain. During the entirety of the in vivo study, the principles of the Ethical Committee for the Protection of Animals in Research of the University of Szeged were strictly followed. The methods used in this work were licensed by the Csongrád County Government Office, Directorate for Food Chain Safety and Veterinary Health (the authority competent in animal-welfare issues) under XXI/151/2013.

\section{General toxicological investigation}

From the daily BW data, weight gain for each week and the whole treatment period was assessed. One day after the treatment period, the rats were killed by overdosed urethane (double the anesthetic dose, ${ }^{35}$ given intraperitoneally). The thorax was opened, a blood sample of 3-4 mL taken from the left ventricle, the rats perfused transcardially with $300 \mathrm{~mL}$ saline at $4^{\circ} \mathrm{C}$ temperature to remove blood from the organs, and then dissected. The rats' lungs (primary target in exposure via the airways) and other organs, such as the spleen, liver, kidneys, and the brain (including both hemispheres and the cerebellum), were weighed and relative organ weights (related to $1 / 100 \mathrm{BW}$ and brain weight) calculated. After organs had been weighed, lung samples were halved. The right half was shock-frozen in liquid nitrogen and stored at $-20^{\circ} \mathrm{C}$ for subsequent measurement of biochemical parameters and Ti-level determination, and 
the left half was fixed in $4 \%$ neutral buffered formalin for histopathological examination.

\section{Titanium-level measurements}

The amount of Ti in the lung, blood, and kidney samples of $\mathrm{TiO}_{2}$ NP-treated and control rats was determined by single-particle inductively coupled plasma mass spectrometry (quadrupole 7700x; Agilent, Santa Clara, CA, USA). For that, samples were dried to constant weight at $80^{\circ} \mathrm{C}$ and digested using $3 \mathrm{~mL} \mathrm{HCl} / \mathrm{g}$ wet tissue at $90^{\circ} \mathrm{C}$, then an equal volume of $\mathrm{HNO}_{3}$ was added and digested for another 90 minutes. This procedure has proved necessary to dissolve all $\mathrm{TiO}_{2}$ reliably. ${ }^{36}$ The resulting liquid was filtered on a $0.45 \mathrm{~nm}$ hydrophilic membrane filter and diluted to $100 \mathrm{~mL}$ final volume.

\section{Assessment of oxidative tissue damage: lipid peroxidation and catalase activity}

Lung tissue from all groups (control [C], vehicle-treated [VT], low dose [LD], and high dose [HD]) were freezeclamped rapidly and powdered with a pestle and mortar in liquid nitrogen. For detection of lipid peroxidation by thiobarbituric acid-reactive substance (TBARS) assay and for catalase-activity measurement, $100 \mu \mathrm{g}$ lung-tissue powder was measured from each sample and homogenized in $1 \mathrm{~mL}$ PBS by three cycles of freeze-thawing in liquid nitrogen. Lysates were centrifuged at 8,000 $\mathrm{g}$ for 10 minutes and the supernatant used for the experiments. Protein concentrations of the lysates were determined with Bradford reagent (Bio-Rad, Hercules, CA, USA).

For lipid-peroxidation assessment, the produced malondialdehyde (MDA; a secondary product of lipid peroxidation) was measured: $50 \mu \mathrm{L}$ lysates were incubated with $450 \mu \mathrm{L}$ Lp reagent (15\% trichloroacetic acid, $0.4 \%$ thiobarbituric acid, $0.25 \mathrm{M} \mathrm{HCl}$ ) for 20 minutes at $100^{\circ} \mathrm{C}$. After centrifugation at 2,000 $\mathrm{g}$ for 5 minutes, the absorbance of the supernatant was measured at $532 \mathrm{~nm} .{ }^{37}$ For assessing catalase activity, $5 \mu \mathrm{L}$ tissue lysate was mixed with PBS (50 mM KH $\mathrm{mO}_{4}, 50 \mathrm{mM} \mathrm{Na}_{2} \mathrm{HPO}_{4}$ ) containing $0.1 \% \mathrm{H}_{2} \mathrm{O}_{2}$, and absorbance was measured continuously at $240 \mathrm{~nm}$ for 3 minutes. By using the difference in absorption/ min values, catalase activity was expressed in Bergmeyer units (BU): $1 \mathrm{BU}$ defines enzyme activity at $25^{\circ} \mathrm{C}$, when $1 \mathrm{~g} \mathrm{H}_{2} \mathrm{O}_{2}$ is enzymatically degraded in 1 minute. ${ }^{38}$ Results of TBARS (MDA concentration) assays and of catalase activity were normalized to the protein concentration of each sample.

\section{Cytokine detection}

The cytokine profile of lung tissue was determined in a semiquantitative way from tissue homogenates using a proteome-profiler rat-cytokine array kit (panel A, 29 rat cytokines and chemokines; R\&D Systems, Minneapolis, MN, USA). Factors to be detected by the kit were CINC1, CINC2 $\alpha / \beta$, CINC3, CNTF, fractalkine, GM-CSF, sICAM1, IFN $\gamma$, IL1 $\alpha$, IL1 $\beta$, IL1RA, IL2, IL3, IL4, IL6, IL10, IL13, IL17, IP10, LIX, L-selectin, MIG, MIP1 $\alpha$, MIP3 $\alpha$, CCL5, TIMP1, TNF $\alpha$, and VEGF.

Powdered lung tissue $(20 \mathrm{mg}$ ) was taken from each rat, and these were lumped together group by group to give collective samples of $200 \mathrm{mg}$. They were homogenized in a PBS containing protease-inhibitor cocktail (Roche, Basel, Switzerland) and 1\% Triton X-100. The samples were frozen and thawed three times in liquid nitrogen, and cellular debris was removed by centrifugation at $10,000 \mathrm{~g}$ for 5 minutes. The protein concentration of the supernatants was measured with the Bradford reagent. Supernatant quantity corresponding to $400 \mu \mathrm{g}$ protein was used from each sample for the array. Cytokines in the samples were determined by an ELISA-based procedure, performed according to the array protocol and the instructions provided by the manufacturer. Membranes were developed using Chemi reagent mix (Immobilon; Merck, Darmstadt, Germany) and chemiluminescent signals detected with a C-Digit blot scanner (Li-Cor, Lincoln, NE, USA).

\section{Light and electron microscopy}

For light microscopy, formalin-fixed lung and hilar lymphnode tissue samples were dehydrated and embedded in paraffin using the standard technique. Sections of $3 \mu \mathrm{m}$ were stained with H\&E. Stained sections were photographed and evaluated quantitatively with ImageJ software. ${ }^{39}$ After calibration and validation of the system, objects of interest, ie, macrophages with phagocytosed $\mathrm{TiO}_{2} \mathrm{NPs}$, were marked manually on the digitized light-microscopy image, and the software calculated their number, total area, and typical maximal diameter. For TEM, formalin-fixed, paraffin-embedded specimens were reembedded into plastic (Embed 812, SigmaAldrich), and $70 \mathrm{~nm}$-thick sections were cut, stained with uranium and lead, and placed on oval slot copper grids. They were analyzed using TEM (JEOL 1,400 plus $120 \mathrm{kV}$ ).

\section{Statistics}

From individual data, group means and standard deviation were obtained. Depending on the normality of data 
distribution, checked by the Kolmogorov-Smirnov test, one-way ANOVA, and post hoc Tukey's test (for body and organ weights), general linear model with repeated measures and post hoc Tukey analysis (for BW-growth rate), and nonparametric Kruskal-Wallis ANOVA and post hoc Mann-Whitney $U$ test with Holm correction (for chemical and biochemical data) were applied. $P<0.05$ was set as the limit of significance. The software used was SPSS version 22.0 (IBM, Armonk, NY, USA). Possible linear correlations between data sets were tested by the "linear fit" function of MS Excel. This function uses the least-squares method to fit a straight line to the measurement data and examines the strength of relationship with Fisher's $F$ test.

\section{Results}

\section{Characterization of $\mathrm{TiO}_{2}$ nanorods}

TEM confirmed that the prepared nanomaterial consisted of nanorods in the desired size range. The X-ray-diffraction pattern verified a crystal structure characteristic of anatase. The size of the synthesized $\mathrm{TiO}_{2}$ nanorods was found to be largely uniform with a narrow distribution range. This was verified by dynamic light scattering and TEM in suspension (Figure 1; size-distribution curves and average NP sizes presented in Figure S1). The stability and shelf-life of the synthesized nanomaterial in dry and suspended states was satisfactory, as its properties did not change throughout the experimental period (Figure 1).

\section{Uptake and internalization of nanorods in A549 cells}

NPs were observed on the surface of A549 cells treated with the suspension of $\mathrm{TiO}_{2}$ nanorods by SEM indicating the attachment of NPs to the cell membrane. The chemical composition of the samples, determined by electron microscopy using the EDS detector, further verified the presence of Ti. SEM and TEM images of cells after 24-hour treatment with $0.1 \mathrm{mg} / \mathrm{mL}$ revealed that $\mathrm{TiO}_{2}$ nanorods were not only present on the cell surface but were also internalized, since $\mathrm{TiO}_{2}$ NPs appeared both attached to the membrane (Figure 2C and D) and in the cytoplasm (Figure 3) of the A549 cells. Intracellularly, $\mathrm{TiO}_{2} \mathrm{NPs}$ were localized mainly in electron dense endosomes, in membrane coated
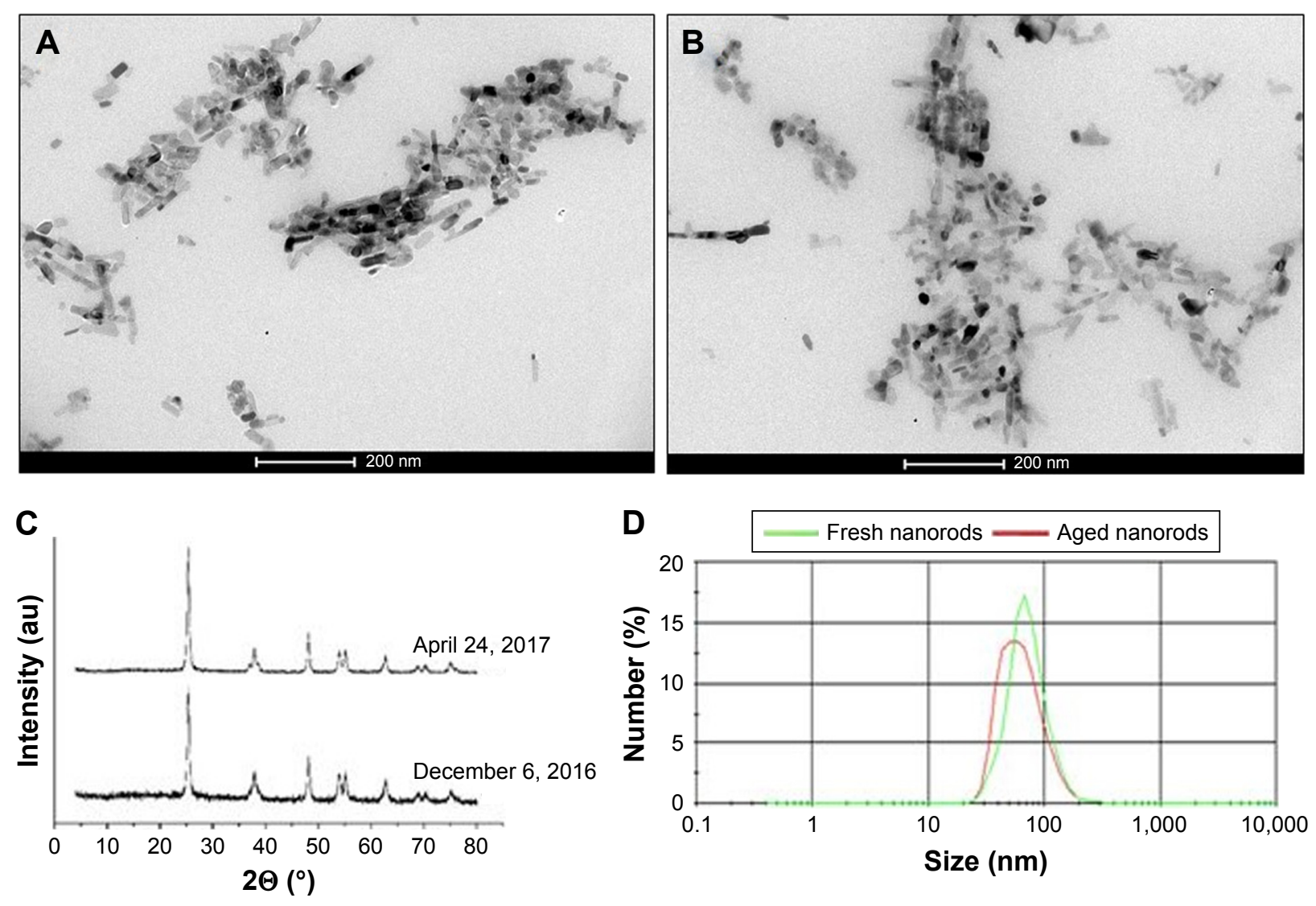

Figure I Characterization of $\mathrm{TiO}_{2}$ nanorods in a fresh state and after $\sim 4$ months of storage.

Notes: TEM images of the new (A) and aged (B) NP suspension; X-ray diffraction patterns (C); size distribution (D) determined by DLS.

Abbreviations: DLS, dynamic light scattering; NP, nanoparticle; TEM, transmission electron microscopy. 

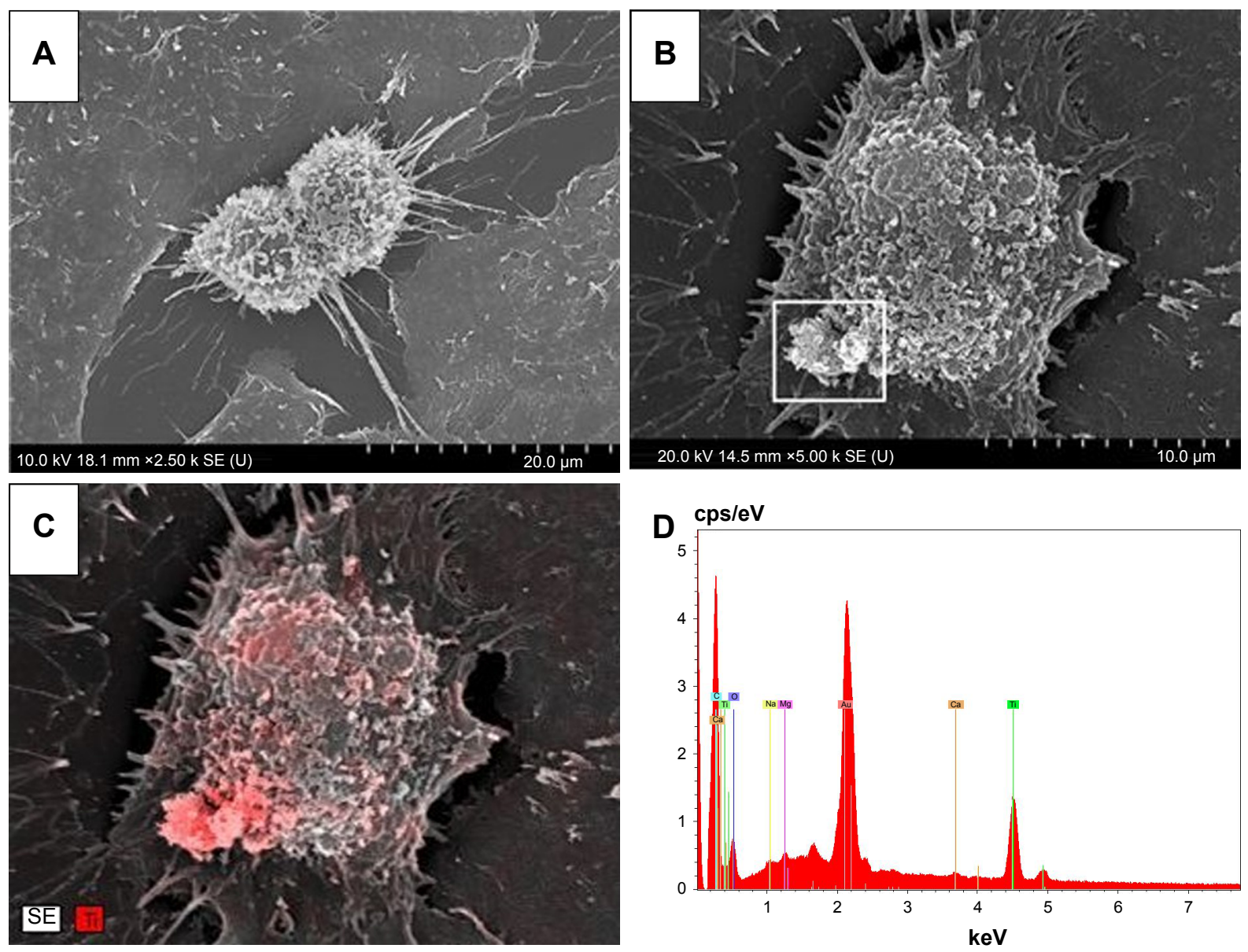

Figure 2 SEM images of control $(\mathbf{A})$ and $\mathrm{TiO}_{2}$ nanorod-treated $\mathrm{A} 549$ cell (B). The cluster of white particles at the lower left region of the cell appeared to be nano-TiO, which was verified by the density of the red color, corresponding to titanium (C), based on the EDS result (D) from the same region. Nanorods in the region with lower red density (C) were probably attached to the plasma membrane, while where red density was maximal, they might have already been internalized.

Abbreviations: EDS, energy-dispersive X-ray spectroscopy; SEM, scanning electron microscopy.

multilamellar and multivesicle bodies. It is of note that no NPs were detected in the nuclei or within the mitochondria of A549 cells.

\section{Effects on cell survival and metabolism}

To evaluate toxicity, A549 cells were treated for 24,48 , or 72 hours with either $\mathrm{TiO}_{2}$ nanorods in various concentrations $(0-2 \mathrm{mg} / \mathrm{mL})$ or with corresponding concentrations of PAA (see Methods section). After treatment, cell viability was determined by MTT assay. Exposure to $\mathrm{TiO}_{2}$ NPs caused dose- and time-dependent viability loss in the A549 cell culture. In Figure 4A, cell viability after 48 hours' exposure is presented. PAA itself exhibited some effect on cell viability, but $\mathrm{TiO}_{2}$ nanorods were significantly more toxic compared to the stabilizing agent. Administration of the nanorods for 48 hours decreased cell viability to a higher degree compared to 24-hour treatments, demonstrating the time-dependent cytotoxicity of $\mathrm{TiO}_{2} \mathrm{NPs}$. At the same time, the presence of
ROS in the treated A549 culture increased to at least double the value of PAA-treated cells detected by DCFDA staining and subsequent quantification of fluorescence intensity (Figure 4B). These results suggested that the reduced cell survival might have been due to apoptosis. Nevertheless, this was not verified by the annexin V-propidium iodide test (data not shown).

\section{General toxicity, effects on the body and organ weights of the treated rats}

Treatment of rats with the $\mathrm{TiO}_{2}$ nanorod suspension at 5 and $18 \mathrm{mg} / \mathrm{kg}$ BW dose (Table 1) had no noteworthy effect on total BW gain (Table 2) or its rate (not shown). In contrast, BW-related weight of the lungs and kidneys increased in all treated groups. Most likely, this showed the effect of both the PAA-containing medium and the NPs themselves, but the net effect of the NPs in the HD group (HD vs VT) was significant (Table 2). 

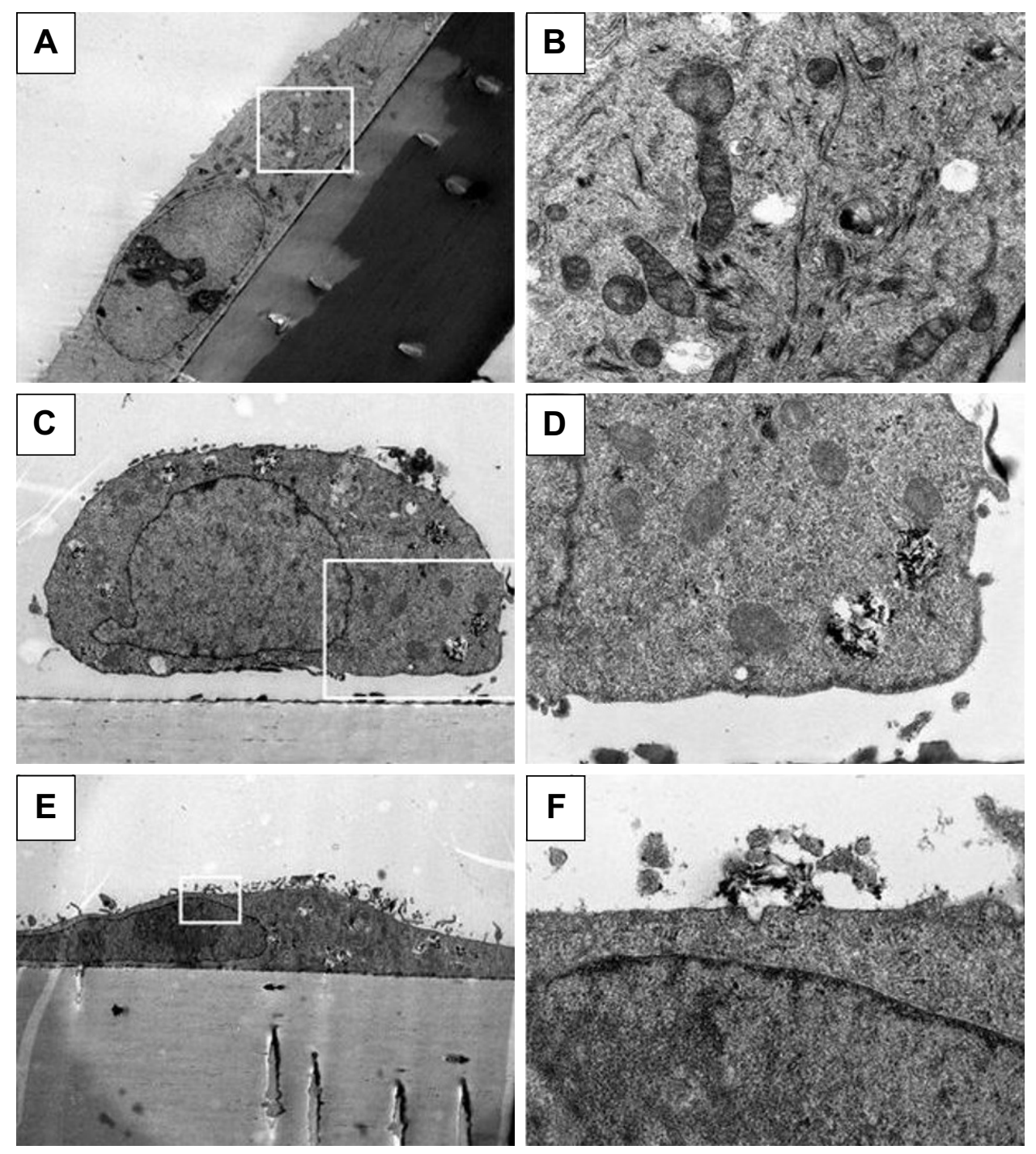

Figure 3 Internalization of $\mathrm{TiO}_{2}$ nanorods by $\mathrm{A} 549$ cells.

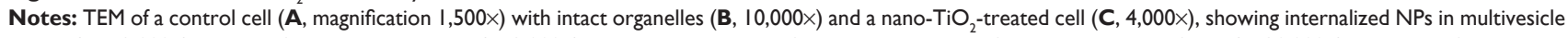
bodies (D, 12,000×). Images of another treated cell (E, 2,000×) reveal a caveola being formed on the cell surface near a cluster of NPs $(\mathbf{F}, 20,000 \times)$. The white frames in $\mathbf{A}$, $\mathbf{C}$, and $\mathbf{E}$ show the cutouts seen magnified in $\mathbf{B}, \mathbf{D}$, and $\mathbf{F}$.

Abbreviations: NPs, nanoparticles; TEM, transmission electron microscopy.

\section{Presence of $\mathrm{TiO}_{2}$ nanorods in treated rat lungs, regional lymph nodes, kidneys, and blood samples}

Chemical analysis by single-particle inductively coupled plasma mass spectrometry revealed significant dose-dependent deposition of Ti in NP-treated rat lungs and much lower levels of Ti in the blood and kidneys (Table 3), indicating that a moderate amount of the NPs managed to get through the alveolar-capillary barrier, most probably in phagosomes of macrophages, as NPs within epithelial cells or free in the interstitium were not observed. The Ti detected in lung tissue was present at least partially in NP form, since H\&E-stained histological sections of the lungs and lymph nodes showed macrophages laden with dark particles (Figure 5); therefore, this histopathology analysis, especially that of lymph nodes, provided further proof that macrophages might be involved in the systemic spreading of the instilled NPs. In the LD and HD nano- $\mathrm{TiO}_{2}$-treated groups, decreased alveolar and increased interstitial area was also observed. Quantification of macrophages in light-microscopy images by means of ImageJ (Table 3) revealed a highly significant and dose-dependent (HD vs LD) difference in their number and also in their size. TEM images, showing NPs and their conglomerates of several hundred nm located within multivesicle bodies in the macrophages (Figure 6), verified the efficient delivery of the NPs by the method of administration used by us. 
A

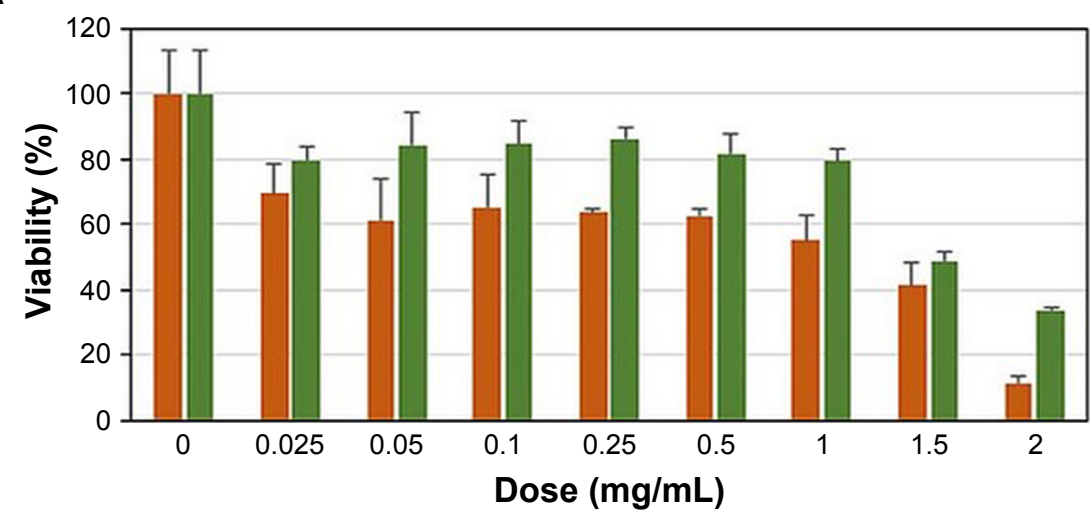

B

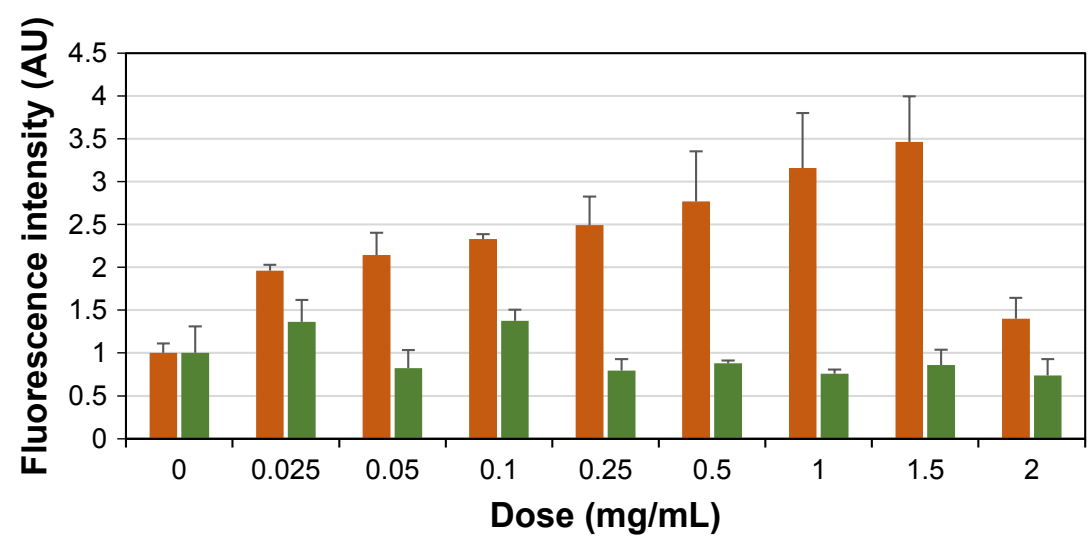

$\because \mathrm{TiO}_{2}+\mathrm{PAA} \square \mathrm{PAA}$

Figure 4 Concentration- and treatment time-dependent decrease in viability $(\mathbf{A})$ and increase in free-radical generation $(\mathbf{B})$ in $\mathrm{A} 594$ cells upon exposure to $\mathrm{TiO}_{2}$ nanorods in culture medium.

Abbreviation: PAA, polyacrylic acid.

\section{Effects of $\mathrm{TiO}_{2} \mathrm{NPs}$ in lung tissue: oxidative stress and cytokine activation} Intracellular (and possibly extracellular) presence of $\mathrm{TiO}_{2}$ NPs in lung tissue of rats treated for 28 days contributed to an overproduction of ROS (analogously to the higher ROS concentration in the $\mathrm{TiO}_{2}$-treated $\mathrm{A} 549$ cells vs $1 \%$

Table 2 Body-weight gain in control and treated rats and relative weight of lungs and kidneys

\begin{tabular}{|l|l|l|l|}
\hline & \multirow{2}{*}{$\begin{array}{l}\text { BW gain } \\
\text { (g) during } \\
\text { treatment }\end{array}$} & \multicolumn{2}{|l|}{$\begin{array}{l}\text { Relative organ weight } \\
\text { (g/100 g BW) }\end{array}$} \\
\cline { 3 - 4 } & Lungs & Kidneys \\
\hline C & $150.80 \pm 30.51$ & $0.52 \pm 0.09$ & $0.77 \pm 0.09$ \\
\hline VT & $167.14 \pm 70.22$ & $0.60 \pm 0.13$ & $0.70 \pm 0.05$ \\
\hline LD & $146.18 \pm 23.36$ & $0.69 \pm 0.07$ & $0.80 \pm 0.07$ \\
\hline HD & $140.51 \pm 13.45$ & $0.86 \pm 0.05 * * \ldots$ & $0.92 \pm 0.05^{\#}$ \\
\hline
\end{tabular}

Notes: Means $\pm S D, n=10$. ${ }^{*} * P<0.01$ vs $C ; \# P<0.01$ vs VT.

Abbreviations: BW, body weight; C, control; HD, high dose (18 mg/kg BW): $\mathrm{LD}$, low dose $(5 \mathrm{mg} / \mathrm{kg} \mathrm{BW})$; VT, vehicle-treated.
PAA-treated cells; Figure 4B), resulting in the generation of considerable oxidative stress. MDA levels (and consequently lipid peroxidation) increased significantly in the HD group only, while catalase activity was significantly raised in both treated groups vs C and VT (Table 4). Also of note is that PAA alone (in group VT) had no effect on these oxidative stress parameters, despite the effect on lung weight (cf Table 2).

The action of $\mathrm{TiO}_{2}$ nanorods on lung-tissue cells induced a massive activation of various cytokines as well, especially within group HD, since the cytokine profile of the HD-group sample demonstrated the expression of several molecules not present in the other samples, including LD (Figure 7). Several of the cytokines detected, such as IL1 $\alpha$ and CINC1, are known to be involved in acute inflammation and phagocyte recruitment. L-selectin promotes diapedesis of the macrophages, whereas VEGF is indicative of the inflammation becoming chronic. 
Table 3 Presence of $\mathrm{Ti}$ in rat lungs, blood, and kidneys: tissue Ti concentrations and image-analysis data of macrophages observed on lung-tissue light microscopy sections

\begin{tabular}{|c|c|c|c|c|c|}
\hline & \multicolumn{3}{|c|}{ Tissue Ti levels ( $\mu \mathrm{g} / \mathrm{kg}$ BW) } & \multicolumn{2}{|c|}{ ImageJ results, $n=10 /$ group } \\
\hline & Lungs, $n=10 /$ group & Blood, $n=8 /$ group & Kidneys, $n=10$ /group & Area & Maximal diameter \\
\hline C & $4.16 \pm 4.12$ & $|53.34 \pm 3| 4.4 \mid$ & $0.21 \pm 0.33$ & ND & ND \\
\hline VT & $2.26 \pm 1.84$ & $205.65 \pm 387.07$ & $2.06 \pm 0.94$ & ND & ND \\
\hline LD & $207.20 \pm 72.85^{* * \ldots \#}$ & $1,077.10 \pm 1,672.47$ & $4.01 \pm 2.19$ & $725.82 \pm 116.85 * * * \ldots \#$ & $34.90 \pm 2.59 * * * \ldots \ldots$ \\
\hline HD & $610.44 \pm 133.03 * *$ \#\# & $\mathrm{I}, \mathrm{I} 82.69 \pm \mathrm{I}, 887.36$ & $7.17 \pm 6.14^{* *}$ & $\mathrm{I}, 196.57 \pm 168.77^{* * * \ldots \ldots \#, 00}$ & $43.00 \pm 2.88 * * *, \ldots \#$, , \\
\hline
\end{tabular}

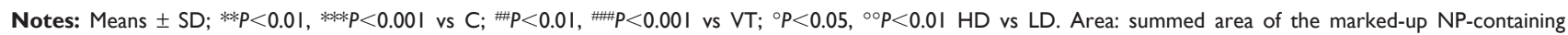
macrophages indicative of their number. Area and diameter given in arbitrary units.

Abbreviations: BW, body weight; C, control; HD, high dose (18 mg/kg BW); LD, low dose (5 mg/kg BW); VT, vehicle-treated.

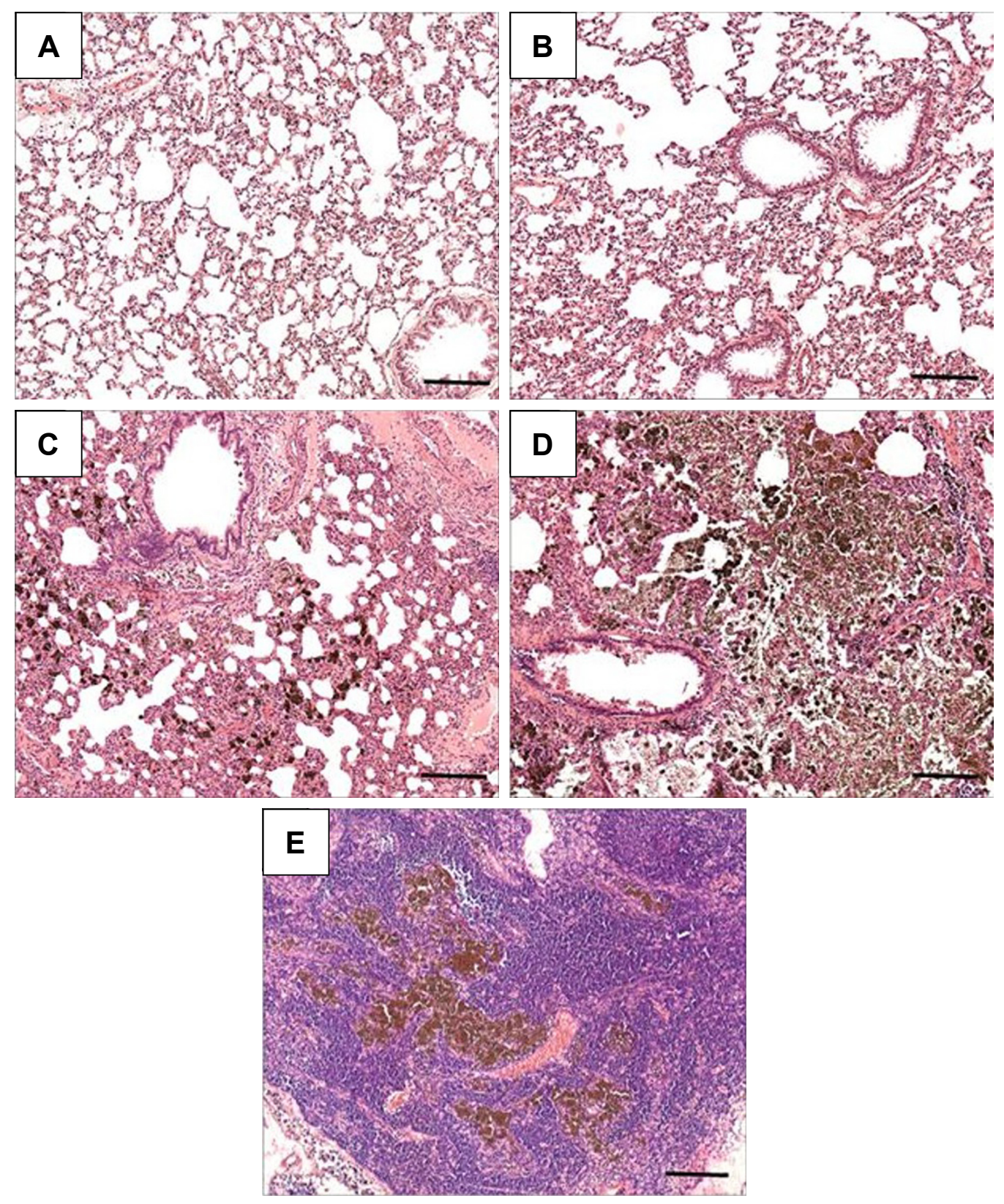

Figure 5 H\&E-stained sections of lung (A-D) and hilar lymph-node (E) tissue from animals in groups C (A), VT (B), LD (C), and HD (D, E).

Notes: (C, D) Macrophages laden with $\mathrm{TiO}_{2}$ NPs and thickened (edematous) interstitial mass; (E) large mass of NP-laden macrophages in the lymph node. Bar $200 \mu \mathrm{m}$. Abbreviations: C, control; HD, high dose ( $18 \mathrm{mg} / \mathrm{kg}$ body weight); LD, low dose $(5 \mathrm{mg} / \mathrm{kg}$ body weight); NP, nanoparticle; VT, vehicle-treated. 

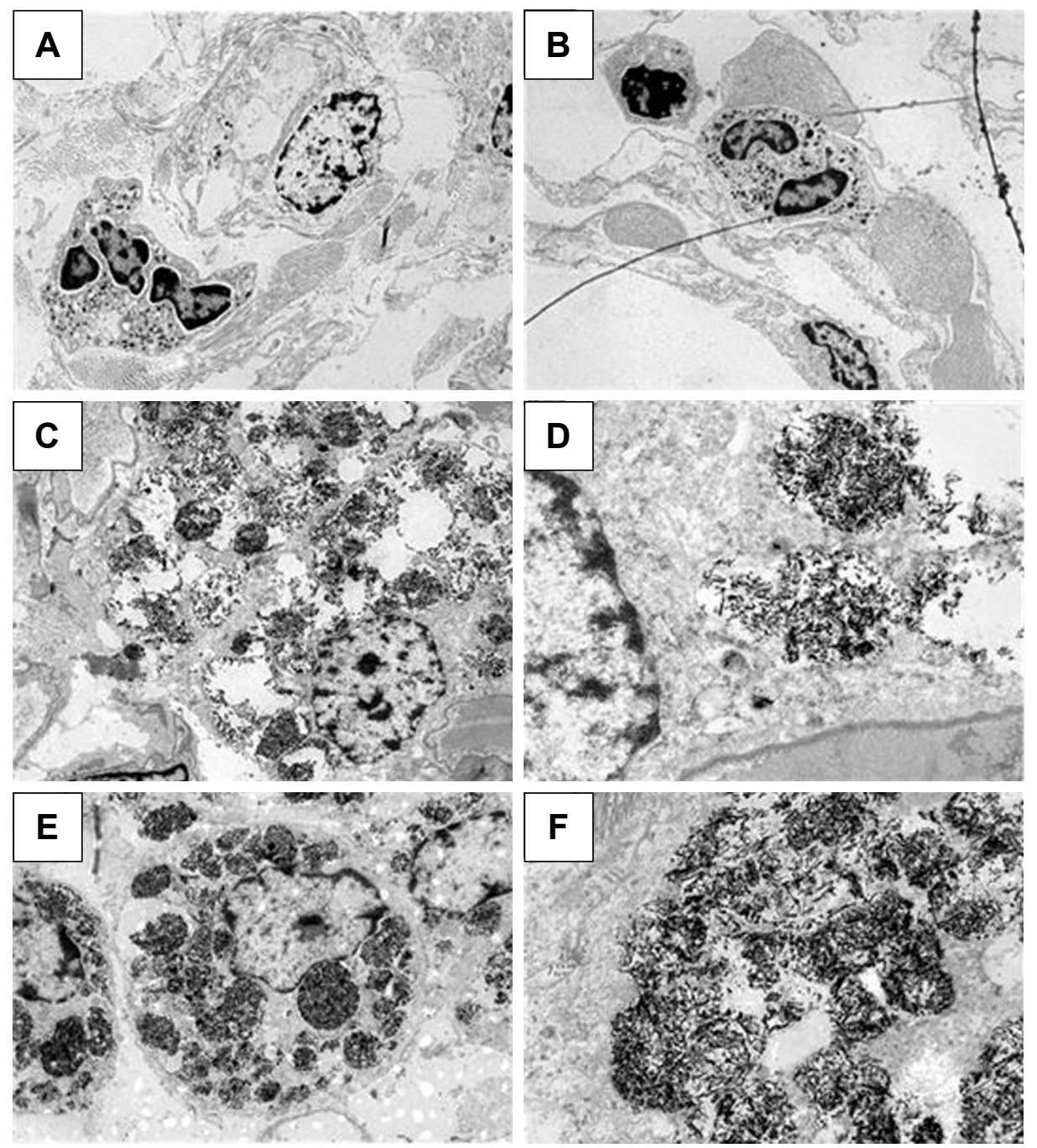

Figure 6 TEM of lung-tissue macrophages from groups C (A), VT (B), LD (C, D), and HD (E, F).

Notes: Magnification: left, 3,000×; right, 12,000×. (D, F) Nanorods within multivesicle bodies can be recognized.

Abbreviations: C, control; HD, high dose (18 mg/kg body weight); LD, low dose (5 mg/kg body weight); TEM, transmission electron microscopy; VT, vehicle-treated.

\section{Discussion}

Application of the synthesized $\mathrm{TiO}_{2}$ nanorods in vitro and in vivo by intratracheal instillation resulted in detectable internal exposure. Not only was their uptake verified both

Table 4 Oxidative stress indicators in control and treated rat lung tissue

\begin{tabular}{|l|l|l|}
\hline & $\begin{array}{l}\text { TBARS } \\
(\mu M \text { MDA/mg protein) }\end{array}$ & $\begin{array}{l}\text { Catalase activity } \\
(B U / m g ~ p r o t e i n)\end{array}$ \\
\hline C & $1.0389 \pm 0.3149$ & $0.00238 \pm 0.00034$ \\
\hline VT & $1.0783 \pm 0.3325$ & $0.00214 \pm 0.00049$ \\
\hline LD & $1.0250 \pm 0.3855$ & $0.00334 \pm 0.00078^{* * \ldots}$ \\
\hline HD & $1.2985 \pm 0.3890 *$ & $0.00345 \pm 0.00105^{* * \ldots}$ \\
\hline
\end{tabular}

Notes: Means $\pm S D ; n=10$. $* P<0.05 ; * * P<0.01$ vs $C ; \# P<0.01$ vs VT.

Abbreviations: BU, Bergmeyer units; C, control; HD, high dose (18 mg/kg body weight); LD, low dose (5 mg/kg body weight); MDA, malondialdehyde; TBARS, thiobarbituric acid-reactive substance; VT, vehicle-treated. chemically (Figure 2, Table 3) and by electron microscopy (phagocytosed NPs and conglomerates in alveolar macrophages, seen in Figure 6D), but moderate effects of cell and tissue damage were evoked following in vitro and in vivo administrations, respectively.

In our in vivo experiment, no clinical signs of toxicity and no mortality were observed in rats treated with 5 and $18 \mathrm{mg} / \mathrm{kg} \mathrm{BW} \mathrm{TiO}{ }_{2} \mathrm{NPs}$. The BW of control and treated rats increased continuously with age, and there were no significant differences in this respect at the end of the treatment. The highest Ti level and relative organ weight of lungs and kidneys in the HD group vs $\mathrm{C}$ group (Tables 2 and 3) indicated local accumulation of $\mathrm{TiO}_{2}$ nanorods and NP-related inflammation after the application of $18 \mathrm{mg} / \mathrm{kg}$ BW $\mathrm{TiO}_{2}$ NPs for 28 days. The low dose $(5 \mathrm{mg} / \mathrm{kg} \mathrm{BW})$, however, had no significant effect on Ti levels or relative 

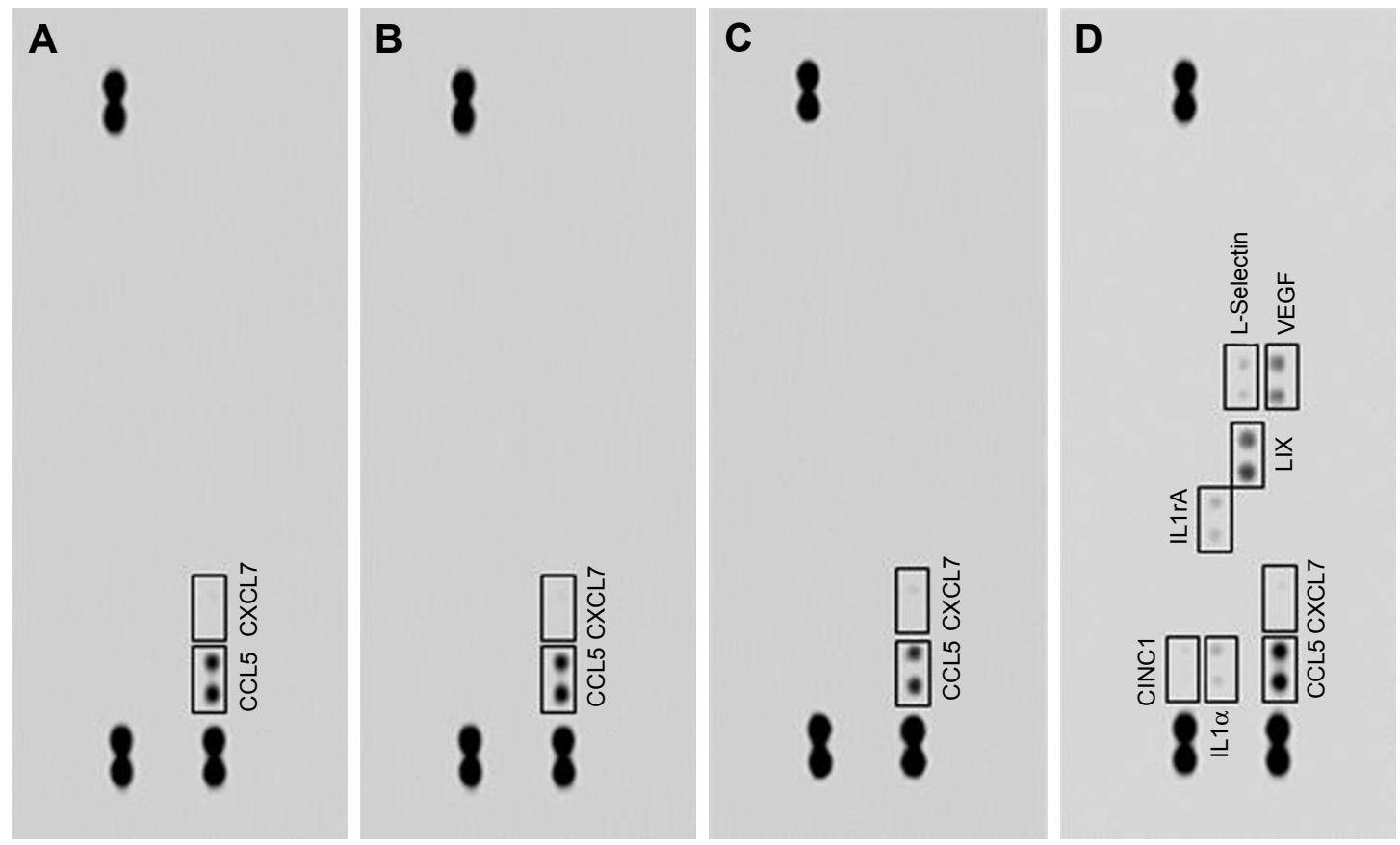

Figure 7 Cytokines detected in lysates of rat lung-tissue samples.

Note: Obtained from animals of groups C (A), VT (B), LD (C), and HD (D) using the rat lung-cytokine array panel.

Abbreviations: C, control; HD, high dose ( $18 \mathrm{mg} / \mathrm{kg}$ body weight); LD, low dose (5 mg/kg body weight); VT, vehicle-treated.

organ weights. All the same, moderate histopathological findings (eg, macrophage proliferation, hyperplasia of the alveolar epithelium or the interstitium; Figure 5, Table 3) were seen in the alveolar region in LD rat lungs. This suggested a dose-dependent pulmonary inflammatory response to the intratracheally administered $15 \times 65 \mathrm{~nm} \mathrm{TiO}_{2}$ nanorods, which was in line with the results of Oyabu et al, who found that NP-induced pulmonary inflammation (its type, extent, and reversibility) depended on the extent of deposition and clearance of NPs in the lung. ${ }^{19}$

Oxidative stress was verified in both test systems. This is not surprising for metal or metal oxide NPs and has also been documented for $\mathrm{TiO}_{2} \mathrm{NPs}^{40,41}$ In the latter study, performed on A549 cells (the strain used also in our work), spherical NPs of various diameters and one elongated, $9 \times 68 \mathrm{~nm}$ rodshaped NP type were examined; however, the rod and one of the spheres had rutile crystal form, whereas the others were anatase. The relationship of size, shape, and crystal form to cytotoxicity and ROS generation was not straightforward, eg, the rutile rods had larger specific surface area, but mostly weaker effect than the rutile spheres of $21 \mathrm{~nm}$ diameter. ${ }^{41}$ Such a relationship, as a possible means of predicting inhalation risk of nano- $\mathrm{TiO}_{2}$ products, has been tested in rats by single intratracheal exposure, ${ }^{29}$ but the outcome was that particle size, but not shape or crystal form, was significantly correlated with indicators of acute pulmonary inflammation.
The findings of Liu et al were partly similar, showing that smaller NPs cause dose-dependently more lung damage, but in that study the crystal form was not unitary ${ }^{42}$ It seems that on the basis of presently available literature, the question of the relationship between physicochemical features (eg, shape) and biological effect of $\mathrm{TiO}_{2} \mathrm{NPs}$ cannot be definitely answered, as was also been concluded in another study. ${ }^{43}$

In the present work, the crystal form of the $\mathrm{TiO}_{2}$ nanorods applied in vitro and in vivo was anatase, which is known to be a chemically more active form than rutile, inducing more severe oxidative stress in biological systems..$^{21}$ The increase in indicators of oxidative stress - elevation of ROS in vitro and of TBARS in vivo (Figure 4, Table 4) - was in line with that, but in contrast to Wadhwa et al, who reported a lack of cytotoxicity of $\mathrm{TiO}_{2}$ nanorods on A549 cells. ${ }^{44}$ However, the nanorods in that study were typically longer than those used by us, and they have been applied in PBS without additives, resulting in aggregation. The actual state of the NPs in the treatment solution, stably suspended in our work due to the addition of PAA (Figure 1), in contrast to aggregation in the mentioned work, may explain the difference in cytotoxicity.

SEM and TEM of $\mathrm{TiO}_{2}$ nanorod-treated A549 cells (Figures 2C, 3, and 6) displayed NPs in both extra- and intracellular positions, including nanorods in multivesicle bodies, verifying internalization of the NPs. The multivesicle 
bodies, membrane-coated cellular organelles containing large amounts of nanorods, potentially indicate the involvement of autophagy-related mechanisms in $\mathrm{TiO}_{2} \mathrm{NP}$-induced toxicity both in vitro and in vivo.

Park et al compared the toxicity of $\mathrm{TiO}_{2}$ nanorods of anatase and brookite crystal form in various cell lines, including the human bronchial epithelial cell line BEAS2B and in mice. ${ }^{45}$ In spite of the smaller specific surface area, brookite nanorods caused more cytotoxicity and oxidative stress in vitro and inflammation of the airways in vivo than anatase, and the authors explained this result by the increased presence of autophagosomes. This is in parallel with our findings in the A549 cell line of alveolar origin (Figure 4).

Autophagy, itself a normal cell-physiology phenomenon, seems to be the ultimate way that NPs induce cell death. ${ }^{11}$ Autophagosomes are formed around cell "garbage" of internal or external origin, where externals may include endocytosed NPs that are attacked by phagocytes of the immune system similarly to pathogens. ${ }^{46}$ The autophagosomes then fuse with lysosomes to degrade their contents. In our nanorod-exposed cells, this process (autophagosomal flux) might have been disturbed, resulting in the accumulation of unprocessed autophagosomes, as was seen in the TEM of $\mathrm{TiO}_{2}$ nanorod treated cells.

Consequences of oxidative stress were observed in the present work, both in vitro (ROS levels in Figure 4) and in vivo (TBARS and catalase-activity levels in Table 4). This is in line with Boland et al, reporting multiple species of ROS and lipid peroxidation in nano- $\mathrm{TiO}_{2}$-treated cells, which then lead to damaged lysosomes. ${ }^{47}$ Lysosomal damage due to increased membrane permeability is potentially enhanced by larger $\mathrm{TiO}_{2}$ NP aggregates. ${ }^{9}$ These can physically break the lysosomal membrane; nevertheless, the overload by indigestible particles alone impedes normal lysosomal flow, ie, fusion with phagosomes. ${ }^{48}$ This way, the normal removal of defected cell constituents is disturbed, resulting in further damage to lysosomes and other organelles, including mitochondria. Beyond that, oxidative damage to membrane lipids may make the penetration of foreign objects, such as NPs and their conglomerates, through the plasma membrane more likely, which in turn may lead to the weakening of endo- and epithelial barriers.

Such enzymes as cathepsin B released from leaky lysosomes would trigger inflammasomes, which in turn activate interleukins. ${ }^{47}$ The spectrum of interleukin activation seen in the lung tissue of HD rats (Figure 7) indicated that acute inflammation developed in the lungs, which turned chronic during the 28-day treatment period. $\mathrm{TiO}_{2} \mathrm{NPs}$ seem to be especially potent in this aspect, inducing the release of both IL $1 \alpha$ and IL $1 \beta .{ }^{49}$ IL $1 \alpha$ - together with IL1RA - was indeed detected in lung tissue of our $\mathrm{HD}^{\mathrm{TiO}}{ }_{2}$ nanorod-treated animals. Increased IL1 has also been detected in mice treated with anatase and brookite nanorods. ${ }^{45}$

Part of the acute inflammatory reaction ${ }^{50}$ and probably induced by the mentioned cytokines, CINC1 is also known to be involved in pulmonary inflammation, as reported by Morimoto et al in a study in which rats were instilled with $\mathrm{TiO}_{2}$ NPs (rutile). ${ }^{51}$ The anatase nanorods used in our work are generally believed to be more inflammogenic than rutile, ${ }^{21}$ so the induction of LIX and increased production of CCL5 in the HD rats was plausible. LIX has also been among the chemokines found in the lungs of mice receiving various metal oxide NPs via the airway. ${ }^{52}$ Beyond its contributing role in inflammation, IL1 is also known to promote autophagy, providing further support to the idea that the cell death seen in our in vitro work was indeed due to autophagy. ${ }^{12}$

The presence of numerous macrophages containing $\mathrm{TiO}_{2}-$ nanorod-laden phagosomes in the lung sections of treated rats (Figures 5 and 6) supported the action of the biochemically detected chemokines. Infiltration of leukocytes into the pulmonary parenchyma and alveolar space by transendothelial migration, as well as increasing interstitial and decreasing alveolar area (Figure 5C and D), was an indication of chronic inflammation and required the coordinated action of several adhesion molecules. The enhanced presence of L-selectin, a surface molecule on leukocytes required for interaction with the endothelium of blood vessels, ${ }^{53}$ in the lung tissue of $\mathrm{TiO}_{2}$ NP-exposed animals (Figure 7) was also in line with that hypothesis. The increased production of the proangiogenic VEGF, also detected in the HD group (Figure 7) indicated that together with L-selectin, local inflammation possibly developed into acute systemic inflammation. The angiogenic action of VEGF and LIX might further promote fibrotic degeneration in the lungs, eventually leading to vanishing of the gas-exchange surface, ie, a COPD-like state. Chronic consequences found in animals due to $\mathrm{TiO}_{2}$ NP exposure include not only pulmonary inflammation, leading to, eg, an asthma-like state, ${ }^{54}$ but also myocarditis ${ }^{55}$ and endothelial damage. ${ }^{56}$ Another consequence of the NP exposure in our study, increased lipid peroxidation (Table 4), has also been implicated in the pathogenesis of oxidative stress-related chronic diseases in the respiratory system (asthma, cystic fibrosis, or interstitial lung disease), ${ }^{57}$ and elsewhere in the body (atherosclerosis, other cardiovascular diseases, alterations in the digestive tract). ${ }^{58}$ Fibroblasts are the most 
essential cell type in the pulmonary interstitium for development and shaping of the alveoli. ROS-dependent impairment (nucleic acid oxidation) in fibroblasts may play a role in the pathogenesis of emphysema. ${ }^{59}$

Elevated Ti levels in blood samples of the treated rats (Table 3) and the presence of nanorod-laden macrophages in the hilar lymph nodes (Figure 5E) may indicate that the alveolar and capillary barrier could not keep $\mathrm{TiO}_{2}$ NPs from causing systemic exposure. This suggests that besides triggering the mentioned inflammogenic effector molecules, nanorods could possibly contribute to damage in distant organs, as in the case of heart damage in nano$\mathrm{TiO}_{2}$-exposed mice. ${ }^{60} \mathrm{How}$ and to what extent NPs can reach distant organs from the lungs and/or cause a systemic exposure are crucial questions. The passage of $\mathrm{TiO}_{2} \mathrm{NPs}$ from the alveoli into the interstitium could be promoted by smaller particles and higher concentrations. ${ }^{61}$ Choi et al found that nanospheres of various chemical compositions with $<34 \mathrm{~nm}$ diameter but not larger penetrated from the alveolar lumen to other pulmonary compartments, including the connective tissues (such as lymph nodes) or the capillary lumen 1-24 hours after exposure. ${ }^{62}$ Very small spheres $(<6 \mathrm{~nm})$ appeared quickly in the kidneys (where they showed slow accumulation), and they were excreted into the urine at 30 minutes postadministration. This sizedependent motility is of high importance, and it supports our findings of increased blood and kidney Ti levels at massive NP deposition in the lungs (Table 3), because (at least in one dimension) the nanorods used by us were in the $<34 \mathrm{~nm}$ size range.

Together with the animal experimental data referred to and some reports on human health risk (such as COPD-like symptoms of nano- $\mathrm{TiO}_{2}$-exposed workers), ${ }^{16}$ our results indicate that whether rod-shaped or spherical, nanoparticulate $\mathrm{TiO}_{2}$ cannot generally be regarded as harmless. In this respect, it is of interest what the two applied doses of $\mathrm{TiO}_{2}$ nanorods, 5 and $18 \mathrm{mg} / \mathrm{kg} \mathrm{BW}$, would mean in terms of human exposure. Based on the daily ventilation volume of rats, ${ }^{63}$ these doses are nominally equal to the atmospheric concentrations of 25 and $90 \mathrm{mg} / \mathrm{m}^{3}$ - around two orders of magnitude higher than the limits of the National Institute for Occupational Safety and Health ${ }^{13}$ - but the 28-day duration of exposure is merely $1 / 30$ of the expectable life span of rats, shorter than a typical job career within the human life span. On the other hand, 5 and $18 \mathrm{mg} / \mathrm{kg}$ BW as instilled experimental doses are not excessive, as judged on the basis of Shakeel et al. ${ }^{30}$

\section{Conclusion}

Intratracheal instillation of $15 \times 65 \mathrm{~nm} \mathrm{TiO}_{2}$ nanorods for 28 days to young healthy rats resulted in oxidative stress and subchronic-like inflammation with incipient fibrotic alterations (thickened interstitium). This suggests that humans, especially with chronic states of the respiratory system like COPD and asthma, might be at higher risk of exposure to airborne nano- $\mathrm{TiO}_{2}$ than has generally been supposed. Translocation of the nanorods to regional lymph nodes and kidneys in the HD group further indicated the risk of damage at systemic level or in distant organs. The occupational health risk suggested by the results calls for improved safety measures. Ideally, limit values and safety measures should be specific to the type of NP present. This, however, would require knowledge that is not available at the moment, which underlines the importance of further studies of the kind presented in this paper.

\section{Acknowledgments}

The authors are thankful to Professor Gábor Galbács and his coworkers from the Department of Inorganic and Analytical Chemistry, Faculty of Science and Informatics, University of Szeged, for the Ti-level measurements. This work was partially financed by the Hungarian National Research, Development, and Innovation Office (NKFIH) through grant GINOP 2.3.2-15-2016-00038.

\section{Disclosure}

The authors report no conflicts of interest in this work.

\section{References}

1. Buzea C, Pacheco II, Robbie K. Nanomaterials and nanoparticles: sources and toxicity. Biointerphases. 2007;2(4):MR17-MR172.

2. International Commission on Radiation Protection (ICRP). Human respiratory tract model for radiological protection. A report of a task group of the ICRP. Ann Int Comm Rad Protect. 1994;24:1-300.

3. Noël A, Charbonneau M, Cloutier Y, Tardif R, Truchon G. Rat pulmonary responses to inhaled nano- $\mathrm{TiO}_{2}$ : effect of primary particle size and agglomeration state. Part Fibre Toxicol. 2013;10:48.

4. Braakhuis HM, Park MV, Gosens I, de Jong WH, Cassee FR. Physicochemical characteristics of nanomaterials that affect pulmonary inflammation. Part Fibre Toxicol. 2014;11:18.

5. Nel A, Xia T, Mädler L, Li N. Toxic potential of materials at the nanolevel. Science. 2006;311(5761):622-627.

6. Oberdörster G, Oberdörster E, Oberdörster J. Nanotoxicology: an emerging discipline evolving from studies of ultrafine particles. Environ Health Perspect. 2005;113(7):823-839.

7. Donaldson K, Tran CL. Inflammation caused by particles and fibers. Inhal Toxicol. 2002;14(1):5-27.

8. Ayres JG, Borm P, Cassee FR, et al. Evaluating the toxicity of airborne particulate matter and nanoparticles by measuring oxidative stress potential - a workshop report and consensus statement. Inhal Toxicol. 2008;20(1):75-99. 
9. Stern ST, Adiseshaiah PP, Crist RM. Autophagy and lysosomal dysfunction as emerging mechanisms of nanomaterial toxicity. Part Fibre Toxicol. 2012;9:20.

10. Farrera C, Fadeel B. It takes two to tango: Understanding the interactions between engineered nanomaterials and the immune system. Eur J Pharm Biopharm. 2015;95(Pt A):3-12.

11. Cohignac V, Landry MJ, Boczkowski J, Lanone S. Autophagy as a possible underlying mechanism of nanomaterial toxicity. Nanomaterials. 2014;4(3):548-582.

12. Harris J. Autophagy and cytokines. Cytokine. 2011;56(2):140-144.

13. National Institute for Occupational Safety and Health (NIOSH). Current Intelligence Bulletin 63: Occupational Exposure to Titanium Dioxide. NIOSH Publication. No 2011-160. Available from: https:// www.cdc.gov/niosh/docs/2011-160/pdfs/2011-160.pdf?id=10.26616/ NIOSHPUB2011160. Accessed October 9, 2018.

14. Koivisto AJ, Lyyränen J, Auvinen A, et al. Industrial worker exposure to airborne particles during the packing of pigment and nanoscale titanium dioxide. Inhal Toxicol. 2012;24(12):839-849.

15. Ling MP, Chio CP, Chou WC, et al. Assessing the potential exposure risk and control for airborne titanium dioxide and carbon black nanoparticles in the workplace. Environ Sci Pollut Res Int. 2011;18(6):877-889.

16. Garabrant DH, Fine LJ, Oliver C, Bernstein L, Peters JM. Abnormalities of pulmonary function and pleural disease among titanium metal production workers. Scand J Work Environ Health. 1987;13(1):47-51.

17. Yoshiura Y, Izumi H, Oyabu T, et al. Pulmonary toxicity of welldispersed titanium dioxide nanoparticles following intratracheal instillation. J Nanopart Res. 2015;17(6):241.

18. van Ravenzwaay B, Landsiedel R, Fabian E, Burkhardt S, Strauss V, Ma-Hock L. Comparing fate and effects of three particles of different surface properties: nano- $\mathrm{TiO}_{2}$, pigmentary $\mathrm{TiO}_{2}$ and quartz. Toxicol Lett. 2009;186(3):152-159.

19. Oyabu T, Morimoto Y, Hirohashi M, et al. Dose-dependent pulmonary response of well-dispersed titanium dioxide nanoparticles following intratracheal instillation. J Nanoparticle Res. 2013;15(4):1600-1610.

20. Lieber M, Smith B, Szakal A, Nelson-Rees W, Todaro G. A continuous tumor-cell line from a human lung carcinoma with properties of type II alveolar epithelial cells. Int J Cancer. 1976;17(1):62-70.

21. Sayes CM, Wahi R, Kurian PA, et al. Correlating nanoscale titania structure with toxicity: a cytotoxicity and inflammatory response study with human dermal fibroblasts and human lung epithelial cells. Toxicol Sci. 2006;92(1):174-185.

22. Ursini CL, Cavallo D, Fresegna AM, et al. Evaluation of cytotoxic, genotoxic and inflammatory response in human alveolar and bronchial epithelial cells exposed to titanium dioxide nanoparticles. $J$ Appl Toxicol. 2014;34(11):1209-1219.

23. Rajamanickam G, Narendhiran S, Muthu SP, Mukhopadhyay S, Perumalsamy R. Hydrothermally derived nanoporous titanium dioxide nanorods/nanoparticles and their influence in dye-sensitized solar cell as a photoanode. Chem Phys Lett. 2017;689:19-25.

24. Wang Y, Yao C, Ding L, et al. Enhancement of the immune function by titanium dioxide nanorods and their application in cancer immunotherapy. J Biomed Nanotechnol. 2017;13(4):367-380.

25. Kulkarni M, Mazare A, Gongadze E, et al. Titanium nanostructures for biomedical applications. Nanotechnology. 2015;26(6):062002.

26. Dastjerdi R, Montazer M. A review on the application of inorganic nano-structured materials in the modification of textiles: focus on antimicrobial properties. Colloids Surf B Biointerfaces. 2010;79(1):5-18.

27. Wang J, Fan Y. Lung injury induced by $\mathrm{TiO}_{2}$ nanoparticles depends on their structural features: size, shape, crystal phases, and surface coating. Int J Mol Sci. 2014;15(12):22258-22278.

28. Blanco E, Shen H, Ferrari M. Principles of nanoparticle design for overcoming biological barriers to drug delivery. Nat Biotechnol. 2015;33(9): 941-951.

29. Hashizume N, Oshima Y, Nakai M, et al. Categorization of nanostructured titanium dioxide according to physicochemical characteristics and pulmonary toxicity. Toxicol Rep. 2016;3:490-500.
30. Shakeel M, Jabeen F, Shabbir S, Asghar MS, Khan MS, Chaudhry AS. Toxicity of nano-titanium dioxide $\left(\mathrm{TiO}_{2}-\mathrm{NP}\right)$ through various routes of exposure: a review. Biol Trace Elem Res. 2016;172(1):1-36.

31. Zhang X, Li W, Yang Z. Toxicology of nanosized titanium dioxide: an update. Arch Toxicol. 2015;89(12):2207-2217.

32. Madarász D, Szenti I, Sápi A, Halász J, Kukovecz Á, Kónya Z. Exploiting the ion-exchange ability of titanate nanotubes in a model water softening process. Chem Phys Lett. 2014;591:161-165.

33. www.icdd.com. [homepage on the Internet]. International Centre for Diffraction Data, PDF-4/Minerals 2018. Newton Square, PA, USA. Available from: www.icdd.com/index.php/pdf-4minerals. Accessed May 7, 2018.

34. Oszlánczi G, Horváth E, Szabó A. Subacute exposure of rats by metal oxide nanoparticles through the airways: general toxicity and neurofunctional effects. Acta Biol Szeged. 2015;54(2):165-170.

35. Koblin DD. Urethane: help or hindrance? Anesth Analg. 2002;94(2): 241-242.

36. Horváth T, Papp A, Kovács D, Kálomista I, Kozma G, Vezér T. Electrophysiological alterations and general toxic signs obtained by subacute administration of titanium dioxide nanoparticles to the airways of rats. Ideggyogy Sz. 2017;70(3-4):127-135.

37. Placer ZA, Cushman LL, Johnson BC. Estimation of product of lipid peroxidation (malonyl dialdehyde) in biochemical systems. Anal Biochem. 1966;16(2):359-364.

38. Beers RF, Sizer IW. Catalase assay with special reference to manometric methods. Science. 1953;117(3052):710-712.

39. Schneider CA, Rasband WS, Eliceiri KW. NIH Image to ImageJ: 25 years of image analysis. Nat Methods. 2012;9(7):671-675.

40. Oberdörster G. Toxicology of ultrafine particles: in vivo studies. Phil Trans $R$ Soc A. 2000;358(1775):2719-2740.

41. Jugan ML, Barillet S, Simon-Deckers A, et al. Titanium dioxide nanoparticles exhibit genotoxicity and impair DNA repair activity in A549 cells. Nanotoxicology. 2012;6(5):501-513.

42. Liu R, Yin L, Pu Y, et al. Pulmonary toxicity induced by three forms of titanium dioxide nanoparticles via intra-tracheal instillation in rats. Prog Natural Sci. 2009;19(5):573-579.

43. Iavicoli I, Leso V, Bergamaschi A. Toxicological effects of titanium dioxide nanoparticles: a review of in vivo studies. J Nanomaterials. 2012;2012:964381.

44. Wadhwa S, Rea C, O'Hare P, et al. Comparative in vitro cytotoxicity study of carbon nanotubes and titania nanostructures on human lung epithelial cells. J Hazard Mater. 2011;191(1-3):56-61.

45. Park EJ, Lee GH, Shim HW, et al. Comparison of toxicity of different nanorod-type $\mathrm{TiO}_{2}$ polymorphs in vivo and in vitro. $J$ Appl Toxicol. 2014;34(4):357-366.

46. Dykman LA, Khlebtsov NG. Immunological properties of gold nanoparticles. Chem Sci. 2017;8(3):1719-1735.

47. Boland S, Hussain S, Baeza-Squiban A. Carbon black and titanium dioxide nanoparticles induce distinct molecular mechanisms of toxicity. Wiley Interdiscip Rev Nanomed Nanobiotechnol. 2014;6(6):641-652.

48. Monick MM, Powers LS, Walters K, et al. Identification of an autophagy defect in smokers' alveolar macrophages. J Immunol. 2010; 185(9):5425-5435.

49. Yazdi AS, Guarda G, Riteau N, et al. Nanoparticles activate the NLR pyrin domain containing 3 (Nlrp3) inflammasome and cause pulmonary inflammation through release of IL-1 $\alpha$ and IL-1ß. Proc Natl Acad Sci U S A. 2010;107(45):19449-19454.

50. Ghaly A, Marsh DR. Ischaemia-reperfusion modulates inflammation and fibrosis of skeletal muscle after contusion injury. Int J Exp Pathol. 2010;91(3):244-255.

51. Morimoto Y, Izumi H, Yoshiura Y, et al. Comparison of pulmonary inflammatory responses following intratracheal instillation and inhalation of nanoparticles. Nanotoxicology. 2016;10(5):607-618.

52. Cai X, Lee A, Ji Z, et al. Reduction of pulmonary toxicity of metal oxide nanoparticles by phosphonate-based surface passivation. Part Fibre Toxicol. 2017;14(1):13. 
53. Ley K. The role of selectins in inflammation and disease. Trends Mol Med. 2003;9(6):263-268.

54. Kim BG, Lee PH, Lee SH, Park MK, Jang AS. Effect of $\mathrm{TiO}_{2}$ Nanoparticles on inflammasome-mediated airway inflammation and responsiveness. Allergy Asthma Immunol Res. 2017;9(3):257-264.

55. Hong F, Wang L, Yu X, Zhou Y, Hong J, Sheng L. Toxicological effect of $\mathrm{TiO}_{2}$ nanoparticle-induced myocarditis in mice. Nanoscale Res Lett. 2015;10(1):326

56. Han SG, Newsome B, Hennig B. Titanium dioxide nanoparticles increase inflammatory responses in vascular endothelial cells. Toxicology. 2013;306:1-8.

57. Domej W, Oettl K, Renner W. Oxidative stress and free radicals in COPD-implications and relevance for treatment. Int J Chron Obstruct Pulmon Dis. 2014;9:1207-1224.

58. Calenic B, Miricescu D, Greabu M, et al. Oxidative stress and volatile organic compounds: interplay in pulmonary, cardio-vascular, digestive tract systems and cancer. Open Chem. 2015;13(1):1020-1030.
59. Białas AJ, Sitarek P, Miłkowska-Dymanowska J, Piotrowski WJ, Górski P. The role of mitochondria and oxidative/antioxidative imbalance in pathobiology of chronic obstructive pulmonary disease. Oxid Med Cell Longev. 2016;2016:Article ID 7808576.

60. Sheng L, Wang X, Sang X, et al. Cardiac oxidative damage in mice following exposure to nanoparticulate titanium dioxide. J Biomed Mater Res A. 2013;101(11):3238-3246.

61. Ferin J, Oberdörster G, Penney DP. Pulmonary retention of ultrafine and fine particles in rats. Am J Respir Cell Mol Biol. 1992;6(5):535-542.

62. Choi HS, Ashitate Y, Lee JH, et al. Rapid translocation of nanoparticles from the lung airspaces to the body. Nat Biotechnol. 2010;28(12): $1300-1303$.

63. Strohl KP, Thomas AJ, St Jean P, Schlenker EH, Koletsky RJ, Schork NJ. Ventilation and metabolism among rat strains. $J$ Appl Physiol. 1997;82(1):317-323. 


\section{Supplementary material}
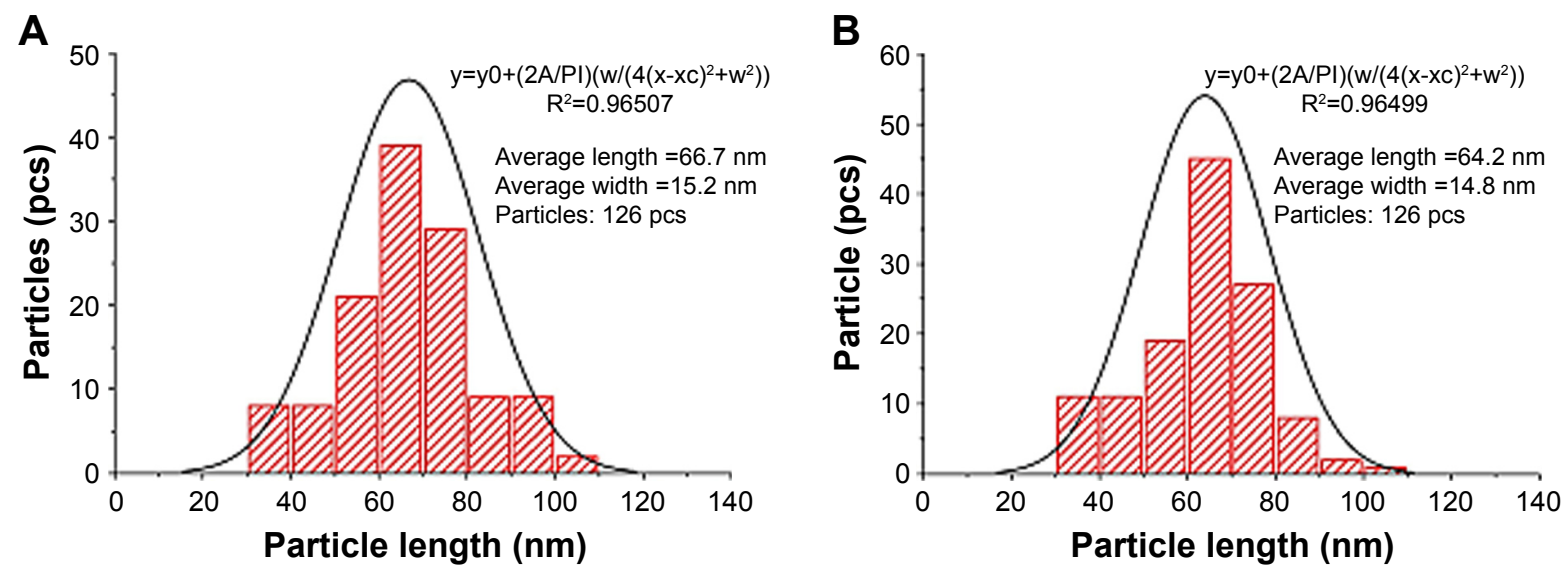

Figure SI Size-distribution curves of $\mathrm{TiO}_{2}$ nanorods in suspension, in fresh state (A), and after 4 months of storage (B).

Note: Equations used to fit the distribution curves and the corresponding coefficient of determination are given in inserts.

\section{Publish your work in this journal}

The International Journal of Nanomedicine is an international, peerreviewed journal focusing on the application of nanotechnology in diagnostics, therapeutics, and drug delivery systems throughou the biomedical field. This journal is indexed on PubMed Central, MedLine, CAS, SciSearch ${ }^{\circledR}$, Current Contents ${ }^{\circledR} /$ Clinical Medicine,
Journal Citation Reports/Science Edition, EMBase, Scopus and the Elsevier Bibliographic databases. The manuscript management system is completely online and includes a very quick and fair peer-review system, which is all easy to use. Visit http://www.dovepress.com/ testimonials.php to read real quotes from published authors. 